\title{
Inflammatory markers and exposure to airborne particles among workers in a Swedish pulp and paper mill
}

\author{
Håkan Westberg ${ }^{1} \cdot$ Karine Elihn $^{2} \cdot$ Eva Andersson $^{4} \cdot$ Bodil Persson $^{3,6}$ • \\ Lennart Andersson $^{1} \cdot$ Ing-Liss Bryngelsson ${ }^{1} \cdot$ Cathe Karlsson $^{5} \cdot$ Bengt Sjögren $^{7}$
}

Received: 19 February 2015 / Accepted: 27 January 2016 / Published online: 13 February 2016

(C) The Author(s) 2016. This article is published with open access at Springerlink.com

\begin{abstract}
Purpose To study the relationship between exposure to airborne particles in a pulp and paper mill and markers of inflammation and coagulation in blood.

Methods Personal sampling of inhalable dust was performed for 72 subjects working in a Swedish pulp and paper mill. Stationary measurements were used to study concentrations of total dust, respirable dust, $\mathrm{PM}_{10}$ and $\mathrm{PM}_{2.5}$, the particle surface area and the particle number concentrations. Markers of inflammation, interleukins (IL1b, IL-6, IL-8, and IL-10), C-reactive protein (CRP), serum amyloid A (SAA), and fibrinogen and markers of coagulation factor VIII, von Willebrand, plasminogen activator inhibitor, and D-dimer were measured in plasma or serum. Sampling was performed on the last day of the work free period of 5 days, before and after the shift the first day
\end{abstract}

Håkan Westberg

hakan.westberg@orebroll.se

1 Department of Occupational and Environmental Medicine, Örebro University Hospital, 70185 Örebro, Sweden

2 Department of Applied Environmental Science, Atmospheric Science Unit, Stockholm University, 10691 Stockholm, Sweden

3 Department of Occupational and Environmental Medicine, Institute of Laboratory Medicine, University Hospital, 221 85 Lund, Sweden

4 Occupational and Environmental Medicine, Sahlgrenska University Hospital, Box 414, 40530 Göteborg, Sweden

5 Billerud AB, 66428 Grums, Sweden

6 Department of Occupational and Environmental Medicine, Linköping University Hospital, 58185 Linköping, Sweden

7 Work Environment Toxicology, Institute of Environmental Medicine, Karolinska Institutet, 17177 Stockholm, Sweden of work and after the shifts the second and third day. In a mixed model analysis, the relationship between particulate exposures and inflammatory markers was determined. Sex, age, smoking, and BMI were included as covariates.

Results The average 8-h time-weighted average (TWA) air concentration levels of inhalable dust were $0.30 \mathrm{mg} / \mathrm{m}^{3}$, range $0.005-3.3 \mathrm{mg} / \mathrm{m}^{3}$. The proxies for average 8 -h TWAs of respirable dust were $0.045 \mathrm{mg} / \mathrm{m}^{3}$. Significant and consistent positive relations were found between several exposure metrics (PM 10, total and inhalable dust) and CRP, SAA and fibrinogen taken post-shift, suggesting a doseeffect relationship.

Conclusion This study supports a relationship between occupational particle exposure and established inflammatory markers, which may indicate an increased risk of cardiovascular disease.

Keywords C-reactive protein (CRP) - Fibrinogen · Interleukins (IL-1b, IL-6, IL-8 and IL-10) $\cdot \mathrm{PM}_{10} \cdot \mathrm{PM}_{2.5}$. Respirable dust $\cdot$ Serum amyloid A (SAA)

\section{Introduction}

Production of pulp and paper is an important sector of Swedish industry with around 42,000 employed. The historical production was dominated by the sulfite process, and today the sulfate process has taken the lead (Nordström et al. 1988; Persson et al. 2007). The occupational chemical exposures in this industry comprised paper and wood dust, chlorine, chlorine dioxide, formaldehyde, terpenes, cutting and lubricating oils, asbestos, and calcium carbonate (Andersson et al. 2010; Kauppinen et al. 2002; Korhonen et al. 2004). The exposures vary a lot between processes and departments (Torén et al. 1996). Further 
exposures include noise, microorganisms, heat, and shift work (Korhonen et al. 2004; Langseth and Kjaerheim 2006). Some studies have observed an increased risk of cardiovascular diseases among pulp and paper mill workers (Andersson et al. 2007; Hammar et al. 1992; Jäppinen and Tola 1990; Langseth and Kjaerheim 2006; Milham and Demers 1984; Persson et al. 2007; Torén et al. 1996) and others have not (Henneberger et al. 1989; Matanoski et al. 1998; Robinson et al. 1986; Sala-Serra et al. 1996; Solet et al. 1989; Wingren et al. 1991; Wong et al. 1996).

In 2010, a writing group of the American Heart Association stated that the overall evidence is consistent with a causal relationship between $\mathrm{PM}_{2.5}$ exposure and cardiovascular morbidity and mortality (Brook et al. 2010). These effects have been found in short-term studies, which relate day-to-day variations in air pollution and health, in long-term studies, which have followed cohorts of exposed individuals over time, and in intervention studies. There is also strong mechanistic evidence from animal and human studies supporting a systemic inflammatory response as the pathway between airborne particle exposure and cardiovascular disease. Other possible biological pathways are disturbances in the autonomic nervous system and direct effects of particles reaching the systemic circulation (Brook et al. 2010).

The inflammatory causal link between inhalation of particulate matter and the incidence of cardiovascular disease was launched as a hypothesis in the mid-1990 (Seaton et al. 1995; Sjögren 1997). Several inflammatory markers, such as interleukin-6, C-reactive protein (CRP), and fibrinogen, are established risk factors for cardiovascular disease (Danesh et al. 1998, 2000, 2005, 2008). Serum amyloid A (SAA) has also been proposed as a risk factor for cardiovascular disease in a battery of several biomarkers (Arant et al. 2009). Studies on qualitative and quantitative associations between particle exposure and inflammatory markers in industrial environments are sparse and have not been performed in the pulp and paper industry.

The purpose was to study the possible exposure-effect relationship between airborne particles and markers of inflammation and coagulation in workers in a pulp and paper mill.

\section{Methods}

\section{Study object and group}

The study was performed at a pulp and paper mill in the middle of Sweden with 850 employees. The mill is one of the largest producers of paper for packaging in Europe. The raw material is softwood as well as hardwood, and the production is based on unbleached and bleached sulfate pulp as well as neutral sulfite semi-chemical (NSSC) pulp. The products has included Kraft paper, sacks, spinning paper, white top liner (WTP), coated paper, sterile paper, sandwich and envelope paper. The departments represented were raw material supply, pulp and paper production, mixing and steam and power production. The exposures varies between different departments, but the main chemical exposures are wood and paper dust, terpenes and bleachery chlorine-based chemicals, calcium hydroxide, sulfur dioxide, hydrogen sulfide, and various reduced sulfur compounds.

The production is performed continuously during day and night in a 5-shift schedule. The shiftwork comprised 8-h for all workers. Production workers in each department, from at least two representative shifts out of a total of 5 , were invited to participate in the study.

The acceptance rate varied between 50 and $90 \%$ in different shifts. In total, 72 subjects, 62 men and 10 women, were investigated. Five workers were excluded due to infectious symptoms, and consequently 67 workers were included in the analysis. Their median age was 46 years (range 25-60 years), and the median duration of employment was 10 years (range $0-38$ ). The shiftwork comprised 8-h for all workers. 16 subjects were current smokers, 16 ex-smokers and 35 were never smokers. The median BMI was 26.7. No personal protective masks were used, only gloves and glasses.

\section{Study design}

The study was performed between May 2007 and February 2009. The investigation comprised aerosol as well as blood sampling the first days after a work free period of generally 5 days. Blood sampling was started in the afternoon (3-4.30 p.m.) the last day of the work free period (day 0), and continued before (4.45-5.45 a.m.) and after the shift the first day of work (day 1) and later after the shifts the second (day 2) and third day (day 3). These post-shift samples were taken between 1.30 and 2.30 p.m. This postshift sampling study design aimed to control for circadian variation. A questionnaire was completed by all participants, containing items about current and previous working conditions, smoking habits, medication, and symptoms of respiratory irritation, infection or other inflammation, which could influence the levels of the biomarkers. Aerosol sampling was performed on the first day (day 1) for all participants.

The study was approved by the Regional Ethical Review Board, Uppsala, id number 2007/51.

\section{Aerosol measurements}

The effects of inhalation of airborne particles have traditionally been focused on coarse and fine particles 
(Brunekreef and Forsberg 2005). In addition particle surface area and particle number have been discussed as agents with inflammatory impact in the lung. Consequently, several exposure metrics, comprising various particle size fractions, have been included. For practical reasons, personal exposure measurements could only be performed for inhalable dust. Other aerosol metrics were determined stationary.

The inhalable dust exposure of the participating subjects was determined with personal sampling measurement, i.e., using personal pumps carried by each worker, the first day after a work free period and the same day as the medical investigations. Personal sampling of inhalable dust was carried out as 8-h full shift samples according to standards for measurement of inhalable dust using GSP-samplers operating at $3.5 \mathrm{l} / \mathrm{min}$, (HSE 2000).

Measuring rigs were used for stationary measurements (area measurements). These measurements were taken at different areas where the workers were present during the work shift, i.e., in the control room as well as along the surveillance tours performed at different departments in the plant. These measurements included sampling of inhalable dust using the same techniques as for the personal samples. Total dust was determined as 8-h full shift samples according to a modified gravimetric method (NIOSH 1994) using an open faced 25-mm filter cassettes (OFC), with an air flow of $2.0 \mathrm{l} / \mathrm{min}$. Respirable dust was determined using SKC aluminum cyclones for $25-\mathrm{mm}$ filters, operating at an air flow of 2.5 1/min (HSE 2000). The $\mathrm{PM}_{10}$ and $\mathrm{PM}_{2.5}$ air concentrations were determined using a Chempass system operating at 1.8 1/min (EN 1999, 2005). Particle surface area concentration was determined using an A-trak 9000 (Aero Trak Nanoparticle Aerosol Monitor) where the particle surface area is determined real-time, ranging in particle size from 10 to $1000 \mathrm{~nm}$. The particle number concentrations in the size range $20-1000 \mathrm{~nm}$ was determined using a real-time aerosol monitoring instrument, (P-Trak 8525, Ultrafine Particle Counter).

In addition to the determined personally sampled exposures of inhalable dust presented as 8-h time-weighted averages (8-h TWAs), the corresponding exposure measures were determined for other aerosol and particle fractions based on the measurements performed in the rig. The TWA exposure regarding respirable and total dust, $\mathrm{PM}_{10}$, $\mathrm{PM}_{2.5}$, particle surface area as well as the particle number concentrations was calculated for each participant. These exposure metrics were estimated by recorded time in different departmental work areas for each worker and the measured aerosol air concentrations at stationary sampling sites representing these work areas. The time spent in different areas was recorded by individual logging of daily work schemes. The individual 8-h TWAs exposures were calculated in the following way for each participant:
$C_{1} \quad$ Air concentration during time period 1 (work area 1$)$, stationary measurement 1

$\begin{array}{ll}C(\text { TWA })= & \left(C_{1} \times T_{1}+C_{2} \times T_{2}+\cdots+C_{n} \times T_{n}\right) \\ & /\left(T_{1}+T_{2}+\cdots+T_{n}\right) \\ C_{n} & \quad \begin{array}{l}\text { Air concentration during time period } n \text { (work } \\ \text { area } n), \text { stationary measurement } n\end{array} \\ T_{1} \quad & \text { Time spent in period } 1 \\ T_{n} & \text { Time spent in period } n\end{array}$

\section{Markers of inflammation and coagulation}

The concentrations of several markers of inflammation and coagulation were determined in serum and plasma; interleukins (IL-1b, IL-6, IL-8, and IL-10), $\gamma$-interferon (IFN $\gamma$ ), tumor necrosis factor- $\alpha(\mathrm{TNF} \alpha)$, CRP, SAA, fibrinogen, factor VIII, von Willebrand factor (vWF), plasminogen activator inhibitor (PAI-1), and D-dimer. All blood samples were centrifuged and frozen to $-70{ }^{\circ} \mathrm{C}$. The analyses were performed at the Clinical Research Center, Örebro University Hospital and at the Department of Occupational and Environmental Medicine, Sahlgrenska University Hospital, Göteborg.

The concentrations of interleukins, IFN $\gamma$, and TNF $\alpha$ were analyzed with a Milliplex Human Cytokine/ Chemokine Immunoassay kit (Millipore Corporation, 290 Concord Road Billerica, MA 01821, USA), the measurements were taken with Luminex 200TM recorder (12212 Technology Blvd, Austin, Texas, USA), and the results were calculated with Luminex xPONENT software.

\section{Statistical analysis}

For descriptive purposes, the aerosol concentrations of different exposure metrics, i.e., inhalable, total, and respirable dust, $\mathrm{PM}_{10}$ and $\mathrm{PM}_{2.5}$, the particle surface area (A-Trak), and the particle number concentration (P-trak) were presented as 8-h TWAs for the full workday. Standard parameters such as arithmetic mean (AM), standard deviation (SD), geometric mean (GM) geometric standard deviation (GSD) and range were calculated for the log normal distribution of all the measurements, including the static samples of the aerosol mass fractions, the concentrations of particle number and particle surface area (Table 1). A corresponding description, mean and range, of the blood concentration by sampling day is also presented (Table 2).

A linear mixed model was applied to describe the relation of the different inflammatory markers and the exposure metrics. Our design and use of mixed model offered a possibility to consider within-and between worker variability for our repeated measurements of inflammatory markers. We used the mixed model to study the biomarker levels between different days compared to day 0 , the reference 
Table 1 Exposure concentration levels of inhalable dust and calculated personal exposure levels of inhalable, total and respirable dust, $\mathrm{PM}_{10}$, $\mathrm{PM}_{2.5}$, particle surface area (A-trak,) and particle number concentrations (P-trak) for all departments

\begin{tabular}{|c|c|c|c|c|c|c|c|c|}
\hline Exposure concentration levels & $N$ & $\mathrm{AM}$ & Median & SD & GM & GSD & Min & $\operatorname{Max}$ \\
\hline \multicolumn{9}{|l|}{ Exposure measurements } \\
\hline Inhalable dust $\left(\mathrm{mg} / \mathrm{m}^{3}\right)$ & 72 & 0.30 & 0.14 & 0.52 & 0.15 & 3.1 & 0.005 & 3.3 \\
\hline \multicolumn{9}{|c|}{ Stationary measurements-calculated exposure levels } \\
\hline Inhalable dust $\left(\mathrm{mg} / \mathrm{m}^{3}\right)$ & 57 & 0.36 & 0.05 & 1.3 & 0.06 & 4.8 & 0.01 & 9.1 \\
\hline Total dust $\left(\mathrm{mg} / \mathrm{m}^{3}\right)$ & 55 & 0.27 & 0.05 & 0.84 & 0.06 & 4.6 & 0.005 & 5.2 \\
\hline Respirable dust $\left(\mathrm{mg} / \mathrm{m}^{3}\right)$ & 55 & 0.045 & 0.025 & 0.06 & 0.026 & 1.1 & 0.004 & 0.29 \\
\hline $\mathrm{PM}_{10}\left(\mathrm{mg} / \mathrm{m}^{3}\right)$ & 47 & 0.17 & 0.10 & 0.25 & 0.11 & 2.3 & 0.03 & 1.5 \\
\hline $\mathrm{PM}_{2.5}\left(\mathrm{mg} / \mathrm{m}^{3}\right)$ & 45 & 0.08 & 0.05 & 0.097 & 0.04 & 3.6 & 0.004 & 0.45 \\
\hline Total particle area (A-trak) $\left(\mu \mathrm{m}^{2} / \mathrm{cm}^{3}\right)$ & 55 & 110 & 38 & 200 & 19 & 18 & 0.001 & 1000 \\
\hline Particle number $\left(\mathrm{P}\right.$-trak) $/ \mathrm{cm}^{3}$ & 55 & 41,000 & 19,000 & 60,000 & 12,000 & 9 & 22 & 270,000 \\
\hline
\end{tabular}

$N$ number of measurements, $A M$ arithmetic mean, $S D$ standard deviation, $G M$ geometric mean, $G S D$ geometric standard deviation

Table 2 Blood concentrations of biological markers, median (minimum-maximum) among 67 participants in different days

\begin{tabular}{|c|c|c|c|c|c|}
\hline Biological marker & $\begin{array}{l}\text { Afternoon } \\
\text { Day } 0\end{array}$ & $\begin{array}{l}\text { Pre-shift } \\
\text { Day } 1\end{array}$ & $\begin{array}{l}\text { Post-shift } \\
\text { Day } 1\end{array}$ & $\begin{array}{l}\text { Post-shift } \\
\text { Day } 2\end{array}$ & $\begin{array}{l}\text { Post-shift } \\
\text { Day } 3\end{array}$ \\
\hline \multicolumn{6}{|l|}{ Inflammation } \\
\hline IL-1b (pg/ml) & $2.3(2.3-440)$ & $3.4(2.3-410)$ & $2.3(2.3-480)$ & $2.3(2.3-610)$ & $2.3(2.3-510)^{\mathrm{a}}$ \\
\hline IL-6 (pg/ml) & $4.8(2.3-680)$ & $7.7(2.3-540)$ & $5.7(2.3-330)$ & $4.1(2.3-340)$ & $4.2(2.3-510)^{\mathrm{a}}$ \\
\hline IL-8 (pg/ml) & $5.1(2.3-84)$ & $6.1(2.3-97)$ & $4.3(2.3-37)$ & $3.9(2.3-27)^{\mathrm{b}}$ & $4.2(2.3-31)^{\mathrm{a}}$ \\
\hline IL-10 (pg/ml) & $7.1(2.3-1000)$ & $8.2(2.3-820)$ & $5.5(2.3-570)$ & $6.3(2.3-610)$ & $6(2.3-860)^{\mathrm{a}}$ \\
\hline $\mathrm{IFN} \gamma(\mathrm{pg} / \mathrm{ml})$ & $2.3(2.3-160)$ & $2.3(2.3-32)$ & $2.3(2.3-29)$ & $2.3(2.3-25)$ & $2.3(2.3-44)^{\mathrm{a}}$ \\
\hline $\mathrm{TNF} \alpha(\mathrm{pg} / \mathrm{ml})$ & $6.8(2.3-160)$ & $8(3.5-130)$ & $6.5(2.3-160)$ & $6.4(2.3-200)$ & $7.1(2.3-170)$ \\
\hline CRP (mg/l) & $1.3(0.13-27)$ & $1.4(0.16-48)$ & $1.5(0.16-42)$ & $1.5(0.15-21)$ & $1.4(0.18-28)$ \\
\hline SAA $(m g / l)$ & $1.7(0.13-65)$ & $2.3(0.39-73)$ & $1.8(0.016-64)$ & $2(0.001-58)$ & $1.6(0.001-63)$ \\
\hline Fibrinogen (g/l) & $2.7(1.7-4.4)$ & $2.7(1.7-4.4)$ & $2.7(1.8-4.5)$ & $2.7(1.8-4.4)$ & $2.7(1.8-4.3)$ \\
\hline \multicolumn{6}{|l|}{ Coagulation } \\
\hline Faktor VIII (kIU/l) & $0.98(0.45-2.1)$ & $1(0.58-2)$ & $1(0.48-1.9)$ & $0.99(0.52-1.8)$ & $1.1(0.58-2)$ \\
\hline vWillebrand (kIU/l) & $1.1(0.52-3.1)$ & $1.1(0.58-2)$ & $1(0.48-2.4)$ & $0.98(0.53-1.9)$ & $0.99(0.56-2)^{\mathrm{b}}$ \\
\hline $\mathrm{PAI}(\mu \mathrm{g} / \mathrm{l})$ & $15(4-80)$ & $25(5-80)$ & $15(2.9-66)$ & $14(2.8-68)$ & $14(2.7-80)^{\mathrm{a}}$ \\
\hline D-dimer $(\mu \mathrm{g} / \mathrm{ml})$ & $0.17(0.11-1.2)$ & $0.16(0.11-1.5)$ & $0.11(0.11-1.5)$ & $0.11(0.11-2.1)$ & $0.15(0.11-11)$ \\
\hline
\end{tabular}

Five workers with infectious symptoms were excluded

a Biological marker with at least one post-shift significantly decreased compared to day 0

b Biological marker with at least one post-shift significantly increased compared to day 0

category (Table 2), and the variation of biomarkers by $Y$ exposure categories 1-4 (Tables 3, 4).

Since the distribution of inflammatory markers was skewed, a transformation to natural logarithm was performed. The estimates $(\beta)$ of the fixed effects from the model allowed us to identify factors affecting inflammatory markers. The mixed model applied has the following equation

$$
\begin{aligned}
Y= & \ln (X)=\mu+\beta_{1}[\mathrm{EXPOSURE}] \\
& +\beta_{2}[\mathrm{DAY}]+\beta_{3}[\mathrm{GENDER}]+\beta_{4}[\mathrm{BMI}] \\
& +\beta_{5}[\mathrm{SMOKING}]+\beta_{6}[\mathrm{AGE}]+\varepsilon
\end{aligned}
$$

$Y \quad \ln (X) ; X$ and $Y$ are the inflammatory marker concentration and log-transformed concentration

$\mu \quad$ the overall average inflammatory marker concentration on log-scale

$\beta_{1} \quad$ the fixed effects of exposure measures $(i \ldots j)$ classified by quartiles with the lowest exposure as reference category (exposure class 1 )

$\beta_{2} \quad$ the fixed effects of sampling time (afternoon days $0,1,2,3)$ with the afternoon day 0 (unexposed) as reference. Pre-shift morning values were not included in the analysis 
Table 3 Mixed model analysis of particle exposure $(n=67)$ and inflammatory markers $(n=335)$ for 67 participants (five workers with infectious symptoms were excluded)

\begin{tabular}{|c|c|c|c|c|c|c|c|c|c|}
\hline \multirow[t]{2}{*}{ Exposure measure } & \multicolumn{3}{|c|}{$\mathrm{CRP}(\mathrm{mg} / \mathrm{l})$} & \multicolumn{3}{|c|}{ SAA $(\mathrm{mg} / \mathrm{l})$} & \multicolumn{3}{|c|}{ Fibrinogen $(\mathrm{g} / \mathrm{l})$} \\
\hline & Mean & SE & $p$ & Mean & SE & $p$ & Mean & SE & $p$ \\
\hline \multicolumn{10}{|c|}{ Inhalable dust $\left(\mathrm{mg} / \mathrm{m}^{3} \mathrm{p}\right)$} \\
\hline \multicolumn{10}{|c|}{ Exp 4} \\
\hline $0.34+$ & 2.77 & 1.35 & 0.021 & 3.13 & 1.35 & 0.104 & 2.87 & 1.06 & 0.231 \\
\hline \multicolumn{10}{|l|}{ Exp 3} \\
\hline $0.15-0.33$ & 0.99 & 1.29 & 0.502 & 1.45 & 1.29 & 0.539 & 2.58 & 1.05 & 0.590 \\
\hline \multicolumn{10}{|l|}{$\operatorname{Exp} 2$} \\
\hline $0.08-0.14$ & 1.29 & 1.37 & 0.909 & 2.69 & 1.37 & 0.227 & 2.82 & 1.06 & 0.348 \\
\hline \multicolumn{10}{|l|}{ Exp 1} \\
\hline$<0.08$ & 1.24 & 1.31 & & 1.79 & 1.31 & & 2.67 & 1.05 & \\
\hline \multicolumn{10}{|c|}{ Inhalable dust $\left(\mathrm{mg} / \mathrm{m}^{3} \mathrm{~s}\right)$} \\
\hline \multicolumn{10}{|l|}{$\operatorname{Exp} 4$} \\
\hline $0.15+$ & 3.15 & 1.40 & 0.000 & 4.50 & 1.40 & 0.004 & 3.04 & 1.06 & $\mathbf{0 . 0 0 7}$ \\
\hline \multicolumn{10}{|l|}{ Exp 3} \\
\hline $0.06-0.14$ & 1.60 & 1.35 & 0.011 & 2.12 & 1.35 & 0.150 & 2.80 & 1.06 & 0.047 \\
\hline \multicolumn{10}{|l|}{$\operatorname{Exp} 2$} \\
\hline $0.03-0.05$ & 1.52 & 1.29 & 0.015 & 1.82 & 1.29 & 0.307 & 2.80 & 1.05 & 0.049 \\
\hline \multicolumn{10}{|l|}{ Exp 1} \\
\hline$<0.03$ & 0.62 & 1.34 & & 1.25 & 1.34 & & 2.45 & 1.05 & \\
\hline \multicolumn{10}{|l|}{ Total dust $\left(\mathrm{mg} / \mathrm{m}^{3} \mathrm{~s}\right)$} \\
\hline \multicolumn{10}{|l|}{ Exp 4} \\
\hline $0.14+$ & 2.94 & 1.35 & 0.007 & 3.85 & 1.34 & 0.038 & 2.97 & 1.05 & 0.059 \\
\hline \multicolumn{10}{|l|}{$\operatorname{Exp} 3$} \\
\hline $0.06-0.13$ & 1.32 & 1.34 & 0.556 & 1.60 & 1.34 & 0.708 & 2.80 & 1.05 & 0.311 \\
\hline \multicolumn{10}{|l|}{ Exp 2} \\
\hline $0.03-0.05$ & 0.95 & 1.30 & 0.725 & 1.41 & 1.29 & 0.431 & 2.52 & 1.05 & 0.462 \\
\hline \multicolumn{10}{|l|}{ Exp 1} \\
\hline$<0.03$ & 1.07 & 1.30 & & 1.82 & 1.29 & & 2.63 & 1.05 & \\
\hline \multicolumn{10}{|l|}{ PM10 $\left(\mathrm{mg} / \mathrm{m}^{3} \mathrm{~s}\right)$} \\
\hline \multicolumn{10}{|l|}{ Exp 4} \\
\hline $0.14+$ & 3.48 & 1.31 & 0.009 & 4.38 & 1.33 & 0.004 & 3.10 & 1.05 & 0.015 \\
\hline \multicolumn{10}{|l|}{ Exp 3} \\
\hline $0.08-0.13$ & 0.99 & 1.29 & 0.178 & 1.62 & 1.30 & 0.889 & 2.62 & 1.05 & 0.612 \\
\hline \multicolumn{10}{|l|}{ Exp 2} \\
\hline $0.04-0.07$ & 0.65 & 1.33 & 0.019 & 1.36 & 1.34 & 0.543 & 2.47 & 1.05 & 0.176 \\
\hline \multicolumn{10}{|l|}{ Exp 1} \\
\hline$<0.04$ & 1.51 & 1.28 & & 1.70 & 1.29 & & 2.69 & 1.04 & \\
\hline
\end{tabular}

Adjusted mean and SE by exposure classes 1-4 representing quartiles of the different exposure measures (particles size fractions). Inhalable personal, inhalable, total and P10 aerosol fractions

Bold value indicates $p<0.05$

$p$ personal sampling, $s$ stationary sampling

$\beta_{3} \quad$ the fixed effects of gender, male or female with males as the reference category

$\beta_{4} \quad$ the fixed effects of BMI, dichotomized by median, the highest level used as reference category

$\beta_{5} \quad$ the fixed effects of smoking habits, ever, never and ex smoker, never smoker as reference category

$\beta_{6} \quad$ the fixed effects of age dichotomized by median, the oldest group as the reference category residual 
Table 4 Mixed model analysis of particle exposure $(n=67)$ and inflammatory markers $(n=335)$ for 67 participants (five workers with infectious symptoms were excluded)

\begin{tabular}{|c|c|c|c|c|c|c|c|c|c|}
\hline \multirow[t]{2}{*}{ Exposure measure } & \multicolumn{3}{|c|}{$\mathrm{CRP}(\mathrm{mg} / \mathrm{l})$} & \multicolumn{3}{|c|}{$\mathrm{SAA}(\mathrm{mg} / \mathrm{l})$} & \multicolumn{3}{|c|}{ Fibrinogen $(\mathrm{g} / \mathrm{l})$} \\
\hline & Mean & SE & $p$ & Mean & SE & $p$ & Mean & SE & $p$ \\
\hline \multicolumn{10}{|c|}{ Respirable dust (mg/m $\left./ \mathrm{m}^{3} \mathrm{~s}\right)$} \\
\hline \multicolumn{10}{|c|}{ Exp 4} \\
\hline $0.06+$ & 2.22 & 1.49 & 0.079 & 3.04 & 1.48 & 0.165 & 3.02 & 1.07 & $\mathbf{0 . 0 3 8}$ \\
\hline \multicolumn{10}{|l|}{ Exp 3} \\
\hline $0.03-0.05$ & 1.89 & 1.32 & 0.075 & 2.39 & 1.31 & 0.278 & 2.78 & 1.05 & 0.206 \\
\hline \multicolumn{10}{|l|}{$\operatorname{Exp} 2$} \\
\hline $0.02-0.02$ & 1.06 & 1.34 & 0.888 & 1.67 & 1.33 & 0.964 & 2.70 & 1.05 & 0.448 \\
\hline \multicolumn{10}{|l|}{ Exp 1} \\
\hline$<0.02$ & 1.01 & 1.35 & & 1.65 & 1.34 & & 2.58 & 1.05 & \\
\hline \multicolumn{10}{|l|}{ PM2.5 $\left(\mathrm{mg} / \mathrm{m}^{3} \mathrm{~s}\right)$} \\
\hline \multicolumn{10}{|l|}{$\operatorname{Exp} 4$} \\
\hline $0.09+$ & 2.04 & 1.38 & 0.051 & 3.10 & 1.36 & 0.014 & 2.86 & 1.06 & 0.063 \\
\hline \multicolumn{10}{|l|}{ Exp 3} \\
\hline $0.05-0.08$ & 1.35 & 1.36 & 0.416 & 2.36 & 1.34 & 0.090 & 2.72 & 1.05 & 0.296 \\
\hline \multicolumn{10}{|l|}{$\operatorname{Exp} 2$} \\
\hline $0.03-0.04$ & 1.21 & 1.40 & 0.640 & 1.99 & 1.37 & 0.264 & 2.75 & 1.06 & 0.247 \\
\hline \multicolumn{10}{|l|}{ Exp 1} \\
\hline$<0.03$ & 1.02 & 1.28 & & 1.35 & 1.27 & & 2.56 & 1.04 & \\
\hline \multicolumn{10}{|c|}{ Particle surface area $\left(\mu \mathrm{m}^{2} / \mathrm{cm}^{3} \mathrm{~s}\right)$} \\
\hline \multicolumn{10}{|l|}{ Exp 4} \\
\hline $96+$ & 1.82 & 1.38 & 0.297 & 2.50 & 1.38 & 0.339 & 2.86 & 1.06 & $\mathbf{0 . 0 3 8}$ \\
\hline \multicolumn{10}{|l|}{ Exp 3} \\
\hline $47-96$ & 1.41 & 1.30 & 0.778 & 1.93 & 1.31 & 0.851 & 2.76 & 1.05 & 0.157 \\
\hline \multicolumn{10}{|l|}{ Exp 2} \\
\hline $15-46$ & 0.78 & 1.39 & 0.210 & 1.53 & 1.39 & 0.669 & 2.68 & 1.06 & 0.374 \\
\hline \multicolumn{10}{|l|}{ Exp 1} \\
\hline$<15$ & 1.27 & 1.31 & & 1.80 & 1.31 & & 2.53 & 1.05 & \\
\hline \multicolumn{10}{|c|}{ Particle $\mathrm{nr}\left(\mathrm{nr} / 10^{4} \mathrm{~cm}^{3} \mathrm{~s}\right)$} \\
\hline \multicolumn{10}{|l|}{ Exp 4} \\
\hline $3.19+$ & 1.88 & 1.34 & 0.150 & 2.13 & 1.35 & 0.644 & 2.87 & 1.05 & 0.038 \\
\hline \multicolumn{10}{|l|}{ Exp 3} \\
\hline $1.81-3.18$ & 1.58 & 1.29 & 0.357 & 2.14 & 1.30 & 0.638 & 2.81 & 1.04 & 0.093 \\
\hline \multicolumn{10}{|l|}{ Exp 2} \\
\hline $0.43-1.80$ & 0.72 & 1.35 & 0.202 & 1.43 & 1.36 & 0.529 & 2.50 & 1.05 & 0.766 \\
\hline \multicolumn{10}{|l|}{ Exp 1} \\
\hline$<0.43$ & 1.15 & 1.32 & & 1.81 & 1.33 & & 2.54 & 1.05 & \\
\hline
\end{tabular}

Adjusted mean and SE by exposure classes 1-4, representing quartiles of the different exposure measures (particles size fractions). Respirable, PM 2.5, particle surface area and particle number air concentrations

Bold value indicates $p<0.05$

$p$ personal sampling, $s$ stationary sampling

The result of the mixed model analysis is presented as adjusted mean and standard error (SE). For statistical significance we used $p<0.05$.
The analyses were performed after exclusion of five subjects with symptoms of infection, leaving 67 subjects for analysis. The analyses were performed with the SPSS software 22.0. 


\section{Results}

\section{Aerosols}

Personal sampling of inhalable dust from 72 participants showed an 8-h TWA exposure of $0.30 \mathrm{mg} / \mathrm{m}^{3}$ with variation between 0.005 and $3.3 \mathrm{mg} / \mathrm{m}^{3}$, Table 1 . The highest exposure was found in the mixing department, $3.3 \mathrm{mg} / \mathrm{m}^{3}$ and the average $8-\mathrm{h}$ TWA exposure in this department was $1.6 \mathrm{mg} / \mathrm{m}^{3}$.

The calculated mean 8-h TWA of inhalable dust based on stationary measurement, $0.36 \mathrm{mg} / \mathrm{m}^{3}$, did not differ substantially from the mean of the personal measurements, $0.30 \mathrm{mg} / \mathrm{m}^{3}$, but the variation was larger for the stationary measurements.

\section{Markers of inflammation and coagulation}

A series of blood samples from 67 exposed participants were obtained after the exclusion of five subjects with symptoms of infection. All measurements of biological markers of inflammation and coagulation are presented in Table 2. Our mixed model analysis showed significant decrease for most markers (IL-1b, IL-6, IL-8, IL-10, IFN $\gamma$, vWF, and PAI-1) was observed from the afternoon on day 0 and to one or several post-shift days in the workweek. However, there was one exception as factor VIII increased (Data not shown).

Some inflammatory markers showed several positive relations with exposure metrics, Tables 3 and 4. Increasing exposures, regarding the mass-based exposure measures, were related to significant increases in CRP, SAA and fibrinogen. Some of the highest quartiles of exposure of total dust showed a positive significant relation with several interleukins, e.g., IL-1b, IL-6, and IL-10, data not shown. Furthermore, a positive relation was also found between exposure to inhalable dust and IL-8. No significant relationships were found between the highest quartiles of exposures and IFN $\gamma, \mathrm{TNF} \alpha, \mathrm{D}$-dimer, vWF, or PAI-1.

\section{Discussion}

The main result of this study was the positive relation between several exposure metrics of the highest quartiles of exposure and some traditional markers of inflammation; CRP, SAA and fibrinogen. Correlations were found for the exposure metrics $\mathrm{PM}_{10}$, total and inhalable dust and these inflammatory markers. The correlations were generally stronger for larger particles, but some relations were also found for small particles $(20 \mathrm{~nm}-1 \mu \mathrm{m})$. The consistent correlations between the exposure matrices $\left(\mathrm{PM}_{10}\right.$, total and inhalable dust) and the well-established inflammatory markers (CRP, SAA and fibrinogen) supports a relationship between particle exposure and inflammatory markers. We did not observe any increase on a group level for most of the markers of inflammation or coagulation for the workers in this industry during a working week after a non-exposure period of 5 days.

To our knowledge, no data have been presented regarding the relationship between occupational exposure to particles and inflammatory markers in the pulp and paper industry, despite the observed risk of cardiovascular disease within this industry. The strength of this study is the measurement of airborne particles comprising a wide range of sizes from many different departments in the industry. However, the chemical composition has not been analyzed and the composition may differ somewhat in different departments, i.e., wood and paper dust, terpenes and bleachery chlorine-based chemicals, calcium hydroxide, sulfur dioxide, hydrogen sulfide, and various reduced sulfur compounds.

The significant decrease in most biological markers (IL1b, IL-6, IL-8, IL-10, IFN $\gamma$, vWF, and PAI-1) is not well understood. A diurnal variation may play some role as the blood samples were taken 1-2 $\mathrm{h}$ earlier during the workweek (Rudnicka et al. 2007; Vgontzas et al. 2005).

CRP is the most sensitive acute-phase reactant and has widespread clinical use because serum CRP reflects the presence and intensity of inflammation (Li et al. 2012). In the review by Li et al. (2012), significant positive associations between ambient particle exposure and CRP were found in all four cross-sectional studies of children younger than 18 years. In contrast to the studies of children, weaker associations were found in cross-sectional studies conducted on adults. Three occupational studies were identified. Among 37 steel production plant workers, CRP levels were significantly positively correlated to the air concentrations of $\mathrm{PM}_{1}$ (median 3.6, range 1.7-30.5 $\mu \mathrm{g} /$ $\mathrm{m}^{3}$ ) and coarse PM (median 162, range 71-1190 $\mu \mathrm{g} / \mathrm{m}^{3}$ ) (Bonzini et al. 2010). In a study of welders, a significant increase in CRP was observed 1 day after a mean exposure of $\mathrm{PM}_{2.5}$ at $1.66 \mathrm{mg} / \mathrm{m}^{3}$ (median 1.69, 25th-75th percentile 0.89-2.44) (Kim et al. 2005). In our previous study of workers exposed to particles, generated during processes of welding, cutting, grinding or foundry and concrete work, a relationship was found between particle exposure and CRP the second day of work after a summer vacation. The mean total dust exposure was $0.93 \mathrm{mg} / \mathrm{m}^{3}$ (range $0.034-6.3 \mathrm{mg} / \mathrm{m}^{3}$ ), (Ohlson et al. 2010). CRP also increased among volunteers exposed for 3-5 h to swine dust (Larsson et al. 1994). Thus, several occupational studies observed a relation between particle exposures and increased levels of CRP. 
In the current study, several exposure metrics were correlated with plasma fibrinogen concentrations. The concentration of fibrinogen was not related to any of the measured aerosol fractions in our previous study (Ohlson et al. 2010). Other studies have shown increases after exposure to swine dust (Sjögren et al. 1999), concentrated ambient particles (Ghio et al. 2003), and urban air pollutants in Taipei (Chuang et al. 2007). However, there are some studies observing a significant decrease in fibrinogen in relation to air pollutant exposure. A significant decrease in fibrinogen was observed 6-h post-exposure in non-smoking welders (Kim et al. 2005). A significant decrease in both fibrinogen and thrombocytes was seen in Belfast and Edinburgh. This was discussed as a possible early consumption coagulopathy (Seaton et al. 1999).

The possible relation between air pollutants and SAA is less frequently studied (Ruckerl et al. 2011). However, one study of patients with coronary heart disease found a small positive relation between ambient particulate air pollution and SAA (Ruckerl et al. 2006).

In our previous study of industrial workers exposed to particles, generated during processes of welding, cutting, grinding or foundry and concrete work, a relationship was found between particle exposure and plasma levels of IL-6 the first day of work after a summer vacation (Ohlson et al. 2010). The workers in the present study were exposed to lower levels of particles in the pulp and paper industry (mean inhalable dust $0.30 \mathrm{mg} / \mathrm{m}^{3}$ ) compared to the workers of the previous study (mean total dust $0.93 \mathrm{mg} / \mathrm{m}^{3}$ ). Another difference between these two studies is the length of non-exposure period prior to the study. In the present study, the period was generally 5 days and in the previous study it was 4-5 weeks. A long exposure-free interval and a relative high exposure may generate an IL-6 response which is not observed when the exposure-free interval is short and the airborne exposure is relatively low. These two aspects may explain a weak response in the current study which was only significant in the highest quartile of total dust exposure.

Different responses were observed when previously unexposed volunteers and swine farmers were exposed for $3 \mathrm{~h}$ in swine confinement building weighing pigs. IL-6 increased fourfold among the volunteers but only slightly among the farmers with previous recent exposure to this environment (Palmberg et al. 2002). The inflammatory response investigated by bronchiolar alveolar lavage (BAL) was stronger among volunteers exposed once to zinc oxide fume $5 \mathrm{mg} / \mathrm{m}^{3}$ compared with volunteers exposed on three successive days to the same fume. The concentration of IL-6 in BAL was three times higher after the single exposure (Fine et al. 2000). These experiments indicate an adaptation with a milder inflammatory response after recent repeated exposures.
The highest afternoon concentrations of IL-8 and IL-10 were found on day 0 , and the levels were found to be lower in all exposed afternoons. The pattern of this change is somewhat surprising as IL-8 is a pro-inflammatory chemokine which increased in bronchial wash after human exposure to diesel exhaust (Stenfors et al. 2004). IL-10 is a pleiotropic, immune regulatory cytokine that is important in protecting the host from infection-associated diseases, autoimmunity and allergy (Ng et al. 2013). However, we observed a positive significant relation between the highest quartile of inhalable dust exposure and IL-8 and also a positive significant relation between the highest quartile of total dust exposure and IL-10.

Some studies of pulp and paper mill workers have observed an increased risk of cardiovascular mortality (Hammar et al. 1992; Jäppinen and Tola 1990; Langseth and Kjaerheim 2006; Milham and Demers 1984; Persson et al. 2007; Torén et al. 1996). However, to our knowledge, no studies have presented adequate measurements of airborne pollutants and in order to perform dose-response or dose-effect calculations.

An increase in inhalable dust concentration with $0.84 \mathrm{mg} / \mathrm{m}^{3}$ (the mean of lowest quartile $0.05 \mathrm{mg} / \mathrm{m}^{3}$ versus the mean of the highest quartile $0.89 \mathrm{mg} / \mathrm{m}^{3}$ ) was associated with an increase in serum CRP concentration with 1.5, from 1.24 to $2.77 \mathrm{mg} / \mathrm{l}$, Table 3. An increase in CRP from less than $0.9 \mathrm{mg} / \mathrm{l}$ to above $2.4 \mathrm{mg} / \mathrm{l}$ has been associated with a doubled risk of developing coronary heart disease (Danesh et al. 2000). However, the present study compares means of CRP concentrations and the previous study by Danesh compares the highest versus the lowest tertile represented by two cut offs. Consequently, the tentative extrapolated risk of coronary heart disease in the present study is lower than twofold.

The overall evidence from time-series analyses regarding urban air pollutants conducted worldwide has confirmed the existence of a small but consistent association between increased cardiovascular mortality of $0.4 \%$ and short-term $10 \mu \mathrm{g} / \mathrm{m}^{3}$ elevations of $\mathrm{PM}_{10}$. Long-term exposures over years increase the risk for cardiovascular mortality to an even greater extent than exposures over a few days (Brook et al. 2010). An average exposure of $0.89 \mathrm{mg} /$ $\mathrm{m}^{3}$ will theoretically increase the short-term cardiovascular mortality by $36 \%(890 / 10 \times 0.4 \%)$.

This study shows consistent and significant increases in some inflammatory markers (CRP and SAA) when dust exposure (inhalable stationary measured dust, total dust and $\mathrm{PM}_{10}$ ) was $0.14 \mathrm{mg} / \mathrm{m}^{3}$ or higher. It could be argued that measurements from personal sampling of inhalable dust are better measures of individual exposures than the calculated exposure based on time spent in different work areas. However, the only significant positive relationship was between the inhalable dust levels of $0.34 \mathrm{mg} / \mathrm{m}^{3}$ or above and CRP, Table 3. 


\section{Conclusion}

We have determined air exposure to particle mass, particle number and particle surface area air concentrations and inflammatory markers. The mean 8-h TWA of inhalable dust exposure was $0.30 \mathrm{mg} / \mathrm{m}^{3}$, and the range was $0.005-$ $3.3 \mathrm{mg} / \mathrm{m}^{3}$. Several of the exposure metrics were associated with dose-dependent increases in some inflammatory markers in the blood (CRP, SAA, and fibrinogen). These doseeffect relations may indicate an increased risk of cardiovascular disease. We did not observe any increase on a group level for most of the markers of inflammation or coagulation for the workers in this industry during a working week after a non-exposure period of 5 days. Our study group is relatively small, and the findings need to be confirmed by investigating larger number of exposed workers in the pulp and paper industry.

Acknowledgments This study was supported by the Swedish Research Council for Health, Working Life and Welfare, Grant Number 2006-0152.

\section{Compliance with ethical standards}

Conflict of interest The authors declare that they have no interest of conflict.

Informed consent Informed consent was obtained for all individual participants included in the study. The study was approved by the Regional Ethical Review Board, Uppsala, including the informed consent procedures.

Open Access This article is distributed under the terms of the Creative Commons Attribution 4.0 International License (http://creativecommons.org/licenses/by/4.0/), which permits unrestricted use, distribution, and reproduction in any medium, provided you give appropriate credit to the original author(s) and the source, provide a link to the Creative Commons license, and indicate if changes were made.

\section{References}

Andersson E, Persson B, Bryngelsson IL, Magnusson A, Torén K, Wingren G, Westberg H (2007) Cohort mortality of Swedish pulp and paper mill workers-non-malignant diseases. Scand $\mathbf{J}$ Work Environ Health 33:470-478

Andersson E, Persson B, Bryngelsson IL, Magnuson A, Westberg H (2010) Cancer mortality in Swedish cohort of pulp and paper mill workers. Int Arch Occup Environ Health 83:123-132

Arant CB, Wessel TR, Ridker PM, Olson MB, Reis SE, Delia Johnson B, Sharaf BL, Pauly DF, Handberg E, Zineh I, Sopko G, Kelsey SF, Noel Bairey Merz C, Pepine CJ (2009) Multimarker approach predicts adverse cardiovascular events in women evaluated for suspected ischemia: results from the National Heart, Lung, and Blood Institute-sponsored Women's Ischemia Syndrome Evaluation. Clin Cardiol 32:244-250

Bonzini M, Tripodi A, Artoni A, Tarantini L, Marinelli B, Bertazzi PA, Apostoli P, Baccarelli A (2010) Effects of inhalable particulate matter on blood coagulation. J Thromb Haemost 8:662-668
Brook RD, Rajagopalan S, Pope CA 3rd, Brook JR, Bhatnagar A, Diez-Roux AV, Holguin F, Hong Y, Luepker RV, Mittleman MA, Peters A, Siscovick D, Smith SC Jr, Whitsel L, Kaufman JD, American Heart Association Council on Epidemiology and Prevention, Council on the Kidney in Cardiovascular Disease, and Council on Nutrition, Physical Activity and Metabolism (2010) Particulate matter air pollution and cardiovascular disease: an update to the scientific statement from the American Heart Association. Circulation 121:2331-2378

Brunekreef B, Forsberg B (2005) Epidemiological evidence of effects of coarse airborne particles on health. Eur Respir J 26:309-318

Chuang K-J, Chan C-C, Su T-C, Lee C-T, Tang C-S (2007) The effect of urban air pollution on inflammation, oxidative stress, coagulation, and autonomic dysfunction in young adults. Am J Respir Crit Care Med 176:370-376

Danesh J, Collins R, Appleby P, Peto R (1998) Association of fibrinogen, C-reactive protein, albumin, or leukocyte count with coronary heart disease. Meta-analyses of prospective studies. JAMA 279:1477-1482

Danesh J, Whincup P, Walker M, Lennon L, Thomson A, Appleby P, Gallimore JR, Pepys MB (2000) Low grade inflammation and coronary heart disease: prospective study and updated meta-analyses. BMJ 321:199-204

Danesh J, Lewington S, Thompson SG, Lowe GD, Collins R, Kostis JB, Wilson AC, Folsom AR, Wu K, Benderly M, Goldbourt U, Willeit J, Kiechl S, Yarnell JW, Sweetnam PM, Elwood PC, Cushman M, Psaty BM, Tracy RP, Tybjaerg-Hansen A, Haverkate F, de Maat MP, Fowkes FG, Lee AJ, Smith FB, Salomaa V, Harald K, Rasi R, Vahtera E, Jousilahti P, Pekkanen J, D'Agostino R, Kannel WB, Wilson PW, Tofler G, Arocha-Piñango CL, Rodriguez-Larralde A, Nagy E, Mijares M, Espinosa R, Rodriquez-Roa E, Ryder E, Diez-Ewald MP, Campos G, Fernandez V, Torres E, Marchioli R, Valagussa F, Rosengren A, Wilhelmsen L, Lappas G, Eriksson H, Cremer P, Nagel D, Curb JD, Rodriguez B, Yano K, Salonen JT, Nyyssönen K, Tuomainen TP, Hedblad B, Lind P, Loewel H, Koenig W, Meade TW, Cooper JA, De Stavola B, Knottenbelt C, Miller GJ, Cooper JA, Bauer KA, Rosenberg RD, Sato S, Kitamura A, Naito Y, Palosuo T, Ducimetiere P, Amouyel P, Arveiler D, Evans AE, Ferrieres J, Juhan-Vague I, Bingham A, Schulte H, Assmann G, Cantin B, Lamarche B, Després JP, Dagenais GR, Tunstall-Pedoe H, Woodward M, Ben-Shlomo Y, Davey Smith G, Palmieri V, Yeh JL, Rudnicka A, Ridker P, Rodeghiero F, Tosetto A, Shepherd J, Ford I, Robertson M, Brunner E, Shipley M, Feskens EJ, Kromhout D, Dickinson A, Ireland B, Juzwishin K, Kaptoge S, Lewington S, Memon A, Sarwar N, Walker M, Wheeler J, White I, Wood A, Fibrinogen Studies Collaboration (2005) Plasma fibrinogen level and the risk of major cardiovascular diseases and nonvascular mortality: an individual participant meta-analysis. JAMA 294:1799-1809

Danesh J, Kaptoge S, Mann AG, Sarwar N, Wood A, Angleman SB, Wensley F, Higgins JPT, Lennon L, Eiriksdottir G, Rumley A, Whincup PH, Lowe GDO, Gudnason V (2008) Long-term interleukin-6 levels and subsequent risk of coronary heart disease: two new prospective studies and a systematic review. PLoS Med 5(4):e78. doi:10.1371/journal.pmed.0050078

European standard: EN 12341:1998. Air quality determination of the PM10 fraction of suspended particulate matter-reference method and field test procedure to demonstrate reference equvalence of measurments methods. ICS 13.040.20;61.040; CEN 1998

European standard: EN 14907: 2005. Ambient air quality-standard gravimetric measurement method for the determination of PM2.5 mass fraction of suspended particulate matter. ICS 13.040.20; CEN 2005

Fine JM, Gordon T, Chen LC, Kinney P, Falcone G, Sparer J, Beckett WS (2000) Characterization of clinical tolerance to inhaled zinc 
oxide in naive subjects and sheet metal workers. J Occup Environ Med 42:1085-1091

Ghio AJ, Hall A, Bassett MA, Cascio WE, Devlin RB (2003) Exposure to concentrated ambient air particles alters hematologic indices in humans. Inhal Toxicol 15:1465-1478

Hammar N, Alfredsson L, Smedberg M, Ahlbom A (1992) Differences in the incidence of myocardial infarction among occupational groups. Scand J Work Environ Health 18:178-185

Health and Safety Executive (HSE 2000) (2000) MDHDS: general methods for sampling and gravimetric analysis of inhalable and respirable dust. Report no 14/3, February 2000, Suffolk UK

Henneberger PK, Ferris BG Jr, Monson RR (1989) Mortality among pulp and paper workers in Berlin, New Hampshire. Br J Ind Med 46:658-664

Jäppinen P, Tola S (1990) Cardiovascular mortality among pulp mill workers. Br J Ind Med 47:259-262

Kauppinen T, Teschke K, Astrakianakis G, Boffetta P, Colin D, Keefe A, Korhonen K, Liukkonen T, Nicol AM, Pannett B, Westberg H (2002) Assessment of exposure in an international study on cancer risks among pulp, paper, and paper product workers. Am Ind Hyg Assoc J 63:254-261

Kim JY, Chen J-C, Boyce PD, Christiani DC (2005) Exposure to welding fumes is associated with acute systemic inflammatory responses. Occup Environ Med 62:157-163

Korhonen K, Liukkonen T, Ahrens W, Astrakianakis G, Boffetta P, Burdorf A, Heederik D, Kauppinen T, Kogevinas M, Osvoll P, Rix BA, Saalo A, Sunyer J, Szadkowska-Stanczyk I, Teschke K, Westberg H, Widerkiewicz K (2004) Occupational exposure to chemical agents in the paper industry. Int Arch Occup Environ Health 77:451-460

Langseth H, Kjaerheim K (2006) Mortality from non-malignant diseases in a cohort of female pulp and paper workers in Norway. Occup Environ Med 63:741-745

Larsson KA, Eklund AG, Hansson LO, Isaksson BM, Malmberg PO (1994) Swine dust causes intense airways inflammation on in healthy subjects. Am J Respir Crit Care Med 150:973-977

Li Y, Rittenhouse-Olson K, Scheider WL, Mu L (2012) Effect of particulate matter air pollution on C-reactive protein: a review of epidemiologic studies. Rev Environ Health 27:133-149

Matanoski GM, Kanchanaraksa S, Lees PSJ, Tao XG, Royall R, Francis M, Lantry D (1998) Industry-wide study of mortality of pulp and paper mill workers. Am J Ind Med 33:354-365

Milham S, Demers R (1984) Mortality among pulp and paper workers. J Occup Med 26:844-846

National Institute of Occupational Health (NIOSH) (1994) Particulates, not otherwise regulated. Method No. 0500. In: NIOSH Manual of analytical methods, 4th ed. DHHS (NIOSH) Pub. No. 94-113. NIOISH, Cincinnati, OH

Ng THS, Britton GJ, Hill EV, Verhagen J, Burton BR, Wraith DC (2013) Regulation of adaptive immunity; the role of interleukin-10. Front Immunol 4:129. doi:10.3389/fimmu.2013.00129

Nordström T, Sjöberg U, Teder A, Tormund D, Vikström B (1988) Farliga svavelföreningar i sulfatmassafabriken-Var finns riskerna? Toxic compounds of sulphur in the sulphate pulp plantWhere are the risks?. Svenska Träforskningsinstitutet, Sweden (In Swedish)

Ohlson CG, Berg P, Bryngelsson IL, Elihn K, Ngo Y, Westberg H, Sjögren B (2010) Inflammatory markers and exposure to occupational air pollutants. Inhal Toxicol 22:1083-1090
Palmberg L, Larsson B-M, Malmberg P, Larsson K (2002) Airway responses of healthy farmers and nonfarmers to exposure in a swine confinement building. Scand J Work Environ Health 28:256-263

Persson B, Magnusson A, Westberg H, Andersson E, Torén K, Wingren G, Axelson O (2007) Cardiovascular mortality among Swedish pulp and paper mill workers. Am J Ind Med 50:221-226

Robinson CF, Waxweiler RJ, Fowler DP (1986) Mortality among production workers in pulp and paper mills. Scand J Work Environ Health 12:552-560

Ruckerl R, Ibald-Mulli A, Koening W, Schneider A, Woelke G, Cyrys J, Heinrich J, Marder V, Frampton M, Wichmann HE, Peters A (2006) Air pollution and markers of inflammation and coagulation in patients with coronary heart disease. Am J Respir Crit Care Med 173:432-441

Ruckerl R, Schneider A, Breitner S, Cyrys J, Peters A (2011) Health effects of particulate air pollution: a review of epidemiologic evidence. Inhal Toxicol 23:555-592

Rudnicka AR, Rumley A, Lowe GDO, Strachan DP (2007) Diurnal, seasonal, and blood-processing patterns in levels of circulating fibrinogen, fibrin D-dimer, C-reactive protein, tissue plasminogen activator and von Willebrand factor in a 45 year-old population. Circulation 115:996-1003

Sala-Serra M, Sunyer S, Kogevinas M, McFarlane D, Antó JM (1996) Cohort study on cancer mortality among workers in the pulp and paper industry in Catalonia, Spain. Am J Ind Med 30:87-92

Seaton A, MacNee W, Donaldson K, Goddon D (1995) Particulate air pollution and acute health effects. Lancet 345:176-178

Seaton T, Soutar A, Crawford V, Elton R, McNerlan S, Cherrie J, Watt M, Agius R, Stout R (1999) Particulate air pollution and the blood. Thorax 54:1027-1032

Sjögren B (1997) Occupational exposure to dust: inflammation and ischaemic heart disease. Occup Environ Med 54:466-469

Sjögren B, Wang Z, Larsson B-M, Larsson K, Larsson PH, Westerholm $P$ (1999) Increase in interleukin-6 and fibrinogen in peripheral blood after swine dust inhalation. Scand J Work Environ Health 25:39-41

Solet D, Zoloth SR, Sullivan C, Jewett J, Michaels DM (1989) Patterns of mortality in pulp and paper workers. J Occup Med 31:627-630

Stenfors N, Nordenhäll C, Salvi SS, Mudway I, Söderberg M, Blomberg A, Helleday R, Levin J-O, Holgate ST, Kelly FJ, Frew AJ, Sandström T (2004) Different airway inflammatory responses in asthmatic and healthy humans exposed to diesel. Eur Respir J 23:82-86

Torén K, Hagberg S, Westberg H (1996) Health effects of working in pulp and paper mills: exposure, obstructive airways diseases, hypersensitivity reactions, and cardiovascular diseases. Am J Ind Med 29:111-122

Vgontzas AN, Bixler EO, Lin H-M, Prolo P, Trakada G, Chrousos GP (2005) IL-6 and its circadian secretion in humans. Neuroimmunomodulation 12:131-140

Wingren G, Persson B, Thorén K, Axelson O (1991) Mortality pattern among pulp and paper mill workers in Sweden: a case-referent study. Am J Ind Med 20:769-774

Wong O, Ragland DR, Marcero DH (1996) An epidemiologic study of employees at seven pulp and paper mills. Int Arch Occup Environ Health 68:498-507 